\title{
Public Awareness about Tetanus
}

\author{
Muhammad Imran Qadir and Tooba Komal* \\ Institute of Molecular Biology and Biotechnology, Pakistan \\ *Corresponding author: Tooba Komal, Institute of Molecular Biology and Biotechnology, Pakistan
}

$\begin{array}{ll}\text { ARTICLE INFO } & \text { ABSTRACT } \\ \begin{array}{l}\text { Received: } \\ \text { Published: February 06, } 2019\end{array} & \begin{array}{l}\text { Objective of the present study was to estimate the awareness of public about Tetanus. } \\ \text { A total of } 100 \text { subjects participated in this study. The subjects were the students of Baha- } \\ \text { uddin Zakariya University Multan, Pakistan. Tetanus is a bacterial infection which causes } \\ \text { the tightness of the muscles by affecting the nervous system. It can also be called as lock- }\end{array} \\ \begin{array}{ll}\text { Citation: Muhammad Imran Qadir, } \\ \text { Tooba Komal. Public Awareness about } \\ \begin{array}{l}\text { Tetanus. Biomed J Sci \& Tech Res } \\ \text { 14(4)-2019. BJSTR. MS.ID.002581. }\end{array}\end{array} & \begin{array}{l}\text { jatal up to 10-20\% approximately. Clostridium tetani is the bacteria which causes Tetanus. } \\ \text { It was concluded form our questionnaire base study that Tetanus is a bacterial disease. } \\ \text { It is not transmitted from parents to children, and there is no need for surgery, although } \\ \text { medicines and vaccines can be given. }\end{array}\end{array}$

Keywords: Public Awareness; Tetanus; Bacterial Disease

\section{Introduction}

Tetanus is a bacterial infection which causes the tightness of the muscles by affecting the nervous system. It can also be called as lockjaw because the contractions usually occur in the jaw and neck. If not cured, this infection can be life threatening. These infections can be fatal up to $10-20 \%$ approximately. Clostridium tetani causes tetanus. Spores of this bacteria can be found in dust, soil or animal droppings. A deep wound or a cut can be the source of entrance of spores into the host which cause infection. Then these spores spread over the nervous system and produce tetanospasmin, a toxin. This poison blocks the nerve signals coming from spinal cord to the muscles causing stiffness in the neck, jaw, abdomen and chest muscles. It also leads to difficulty in swallowing and even cause sever muscle spasms. Its symptoms include increased rate of heart beat and blood pressure, fever, sweating. Antibiotics such as penicillin can be used for the treatment purposes to kill the bacteria. Vaccines against tetanus are also available. Muscle relaxers and toxin neutralizers can also be used to cure tetanus.

\section{Objective}

Objective of the present study was to estimate public awareness about tetanus.

\section{Materials and Methods}

A total of 100 subjects participated in this project. The subjects were the students of Bahauddin Zakariya University Multan,
Pakistan. In this project, a questionnaire was given to the people (Tables 1-4).

\section{Statistical Analysis}

Statistical analysis was performed by using MS Excel.

\section{Results}

Figures 1-4.

Table 1: Questionnaire to assess awareness about Tetanus

\begin{tabular}{|c|c|c|}
\hline Tetanus is a & Yes & No \\
\hline 1. Fungal infection/disease & & \\
\hline 2. Bacterial disease & & \\
\hline 3. Viral disease & & \\
\hline 4. Metabolic disease & & \\
\hline 5. Genetic disease & & \\
\hline
\end{tabular}

Table 2: Questionnaire to analyze awareness about ubiquity of Tetanu

\begin{tabular}{|c|c|c|}
\hline Ever suffered from Tetanus & Yes & No \\
\hline 1. You & & \\
\hline 2. Your family & & \\
\hline 3. Your relative & & \\
\hline 4. Your neighbor & & \\
\hline 5.Your friend & & \\
\hline 6. & & \\
\hline
\end{tabular}


Table 3: Questionnaire to estimate vision about Tetanus transference.

\begin{tabular}{|c|c|c|}
\hline Tetanus is Disseminated by & Yes & No \\
\hline 1. Contact or blood decantation & & \\
\hline 2. From parents to progeny & & \\
\hline
\end{tabular}

Table 4: Questionnaire to evaluate perspective about treatment of Tetanus.

\begin{tabular}{|c|c|c|}
\hline Tetanus may be medicated by & Yes & No \\
\hline 1. Medicines & & \\
\hline 2. Surgery & & \\
\hline 3. No need of treatment & & \\
\hline
\end{tabular}

\section{Discussion}

Figure 1 shows the awareness of public about Tetanus that whether it is a viral, bacterial, fungal, metabolic or genetic disease. $96 \%$ of the subjects said that it is a bacterial disease. Figure 2 shows the ubiquity of Tetanus that whether the subjects themselves, their relative, friend, family member or neighbor have ever suffered from
Tetanus or not? $4 \%$ of the subjects said that they have been suffered from Tetanus and $96 \%$ said that that they are not. $6 \%$ said that their family members have been infected by Tetanus and $94 \%$ answered No. $29 \%$ of the subjects said that their relative and neighbor have been infected by Tetanus and $71 \%$ answered No. $12 \%$ of the subjects said that their friends have been suffered from Tetanus and $88 \%$ answered No. Figure 3 shows the transference of Tetanus that whether it is transmitted through blood or from parents to off-springs. 55\% of the subjects said that it is transmitted through blood and $45 \%$ said that it is not transmitted by blood. $1 \%$ of the subjects said that it transfers from parents to off-springs and $99 \%$ answered No. Figure 4 shows the treatment of Tetanus that whether it is treated by medicines, surgery or there is no need of treatment? $60 \%$ of the subjects said that it is treated through medicines and $40 \%$ answered No. $1 \%$ of the subjects said that it can be treated by surgery and $99 \%$ said No, that there is no need for surgery. $20 \%$ of the subjects said that there is no need of treatment for Tetanus and $80 \%$ answered No, that there is a need of treatment for Tetanus $[1,2]$.

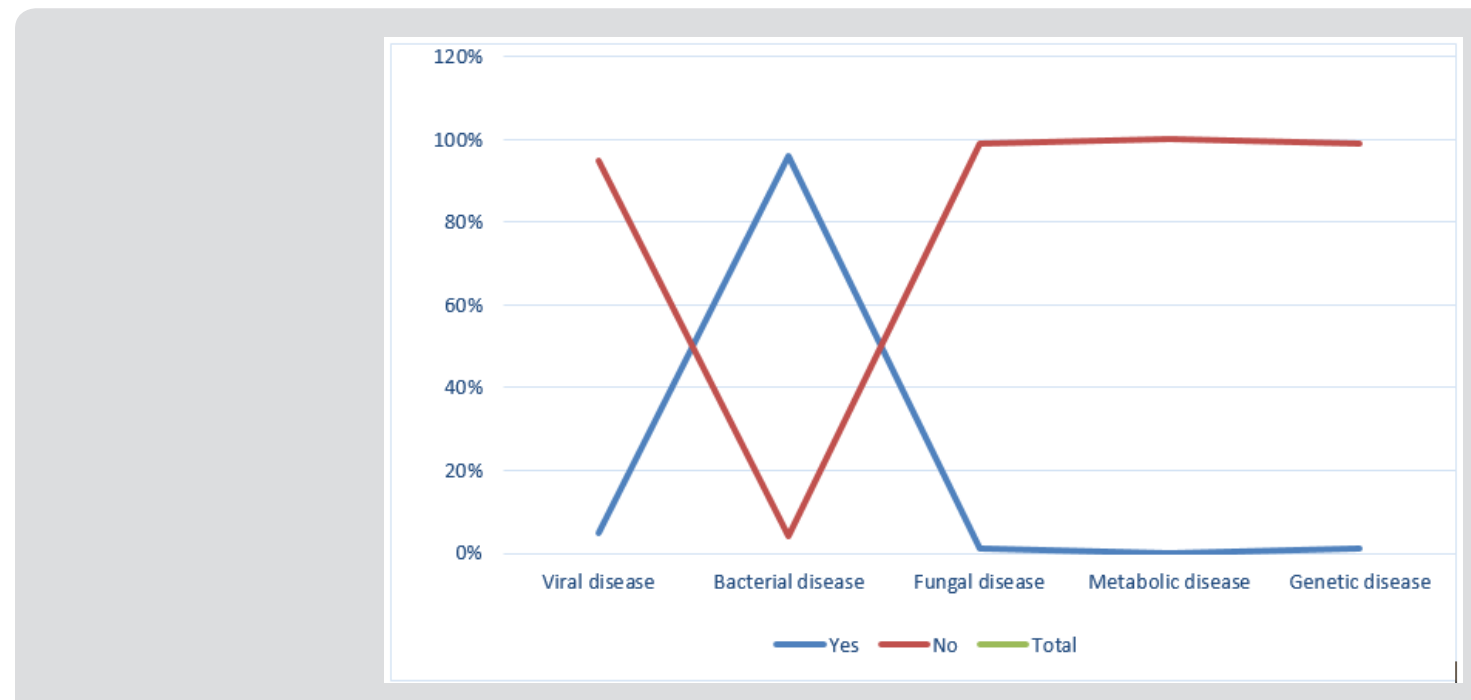

Figure 1: Awareness about Tetanus.

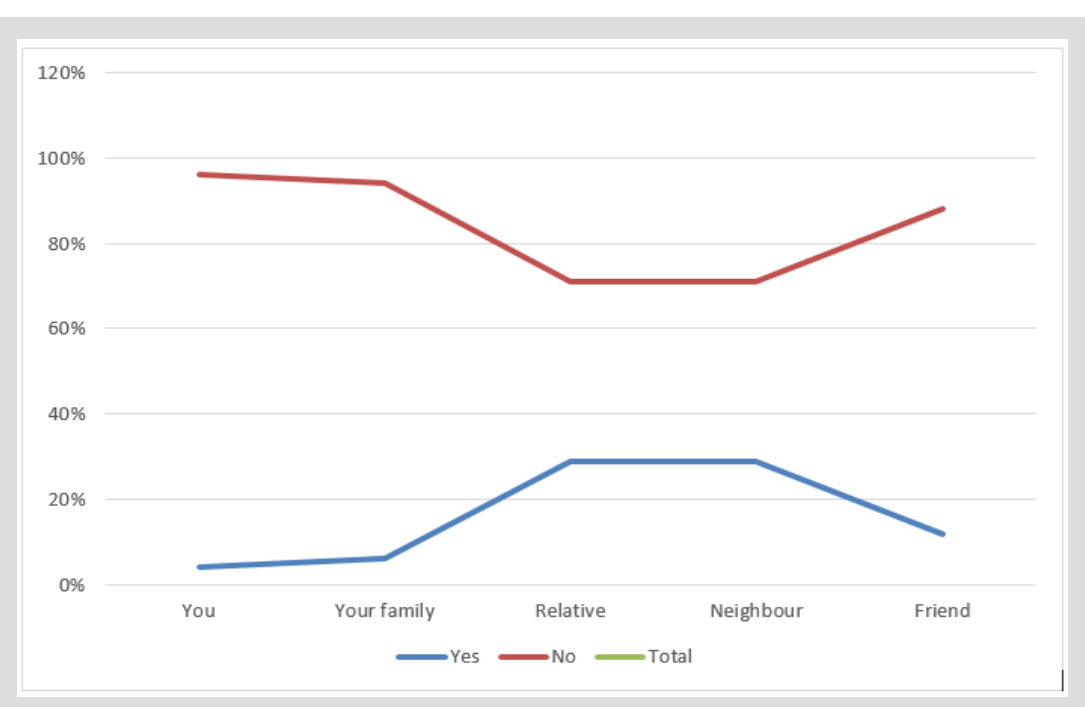

Figure 2: Ubiquity of Tetanus. 


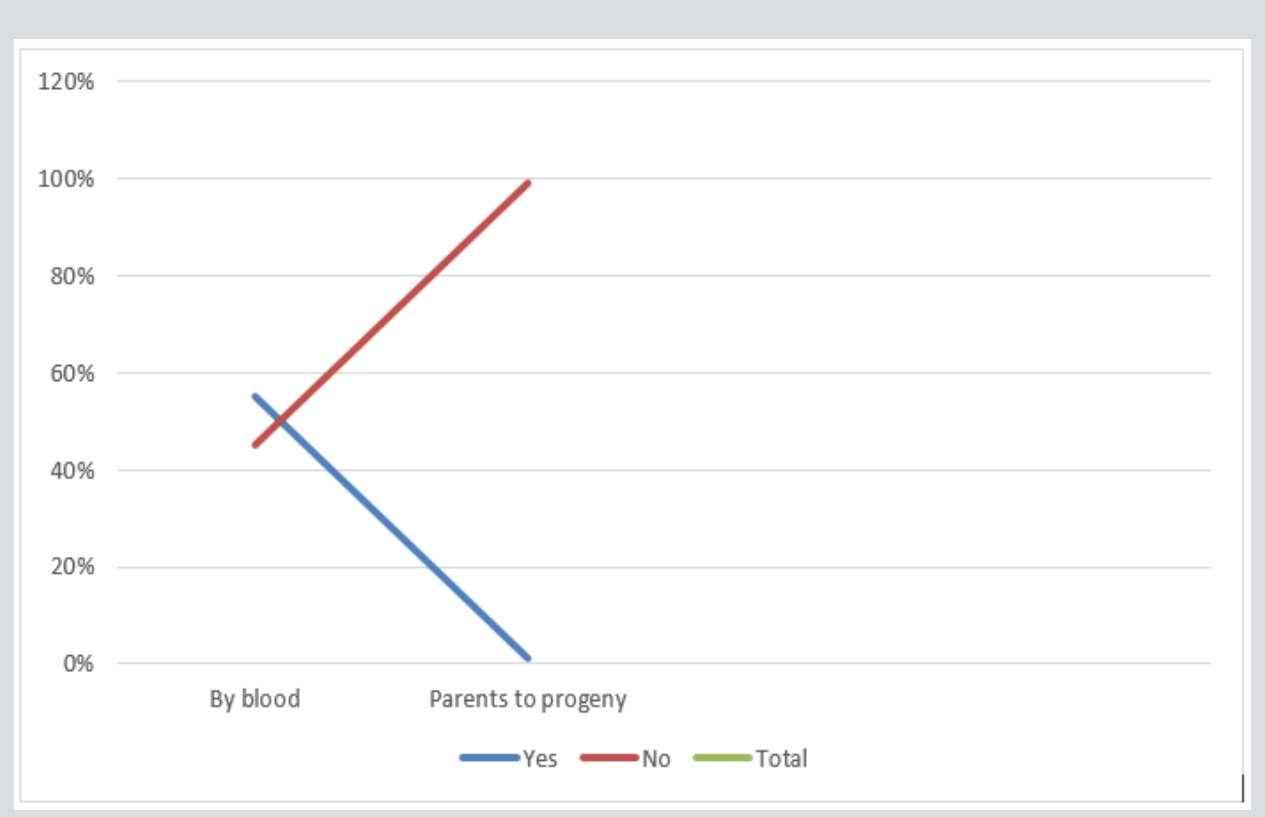

Figure 3: Tetanus transference.

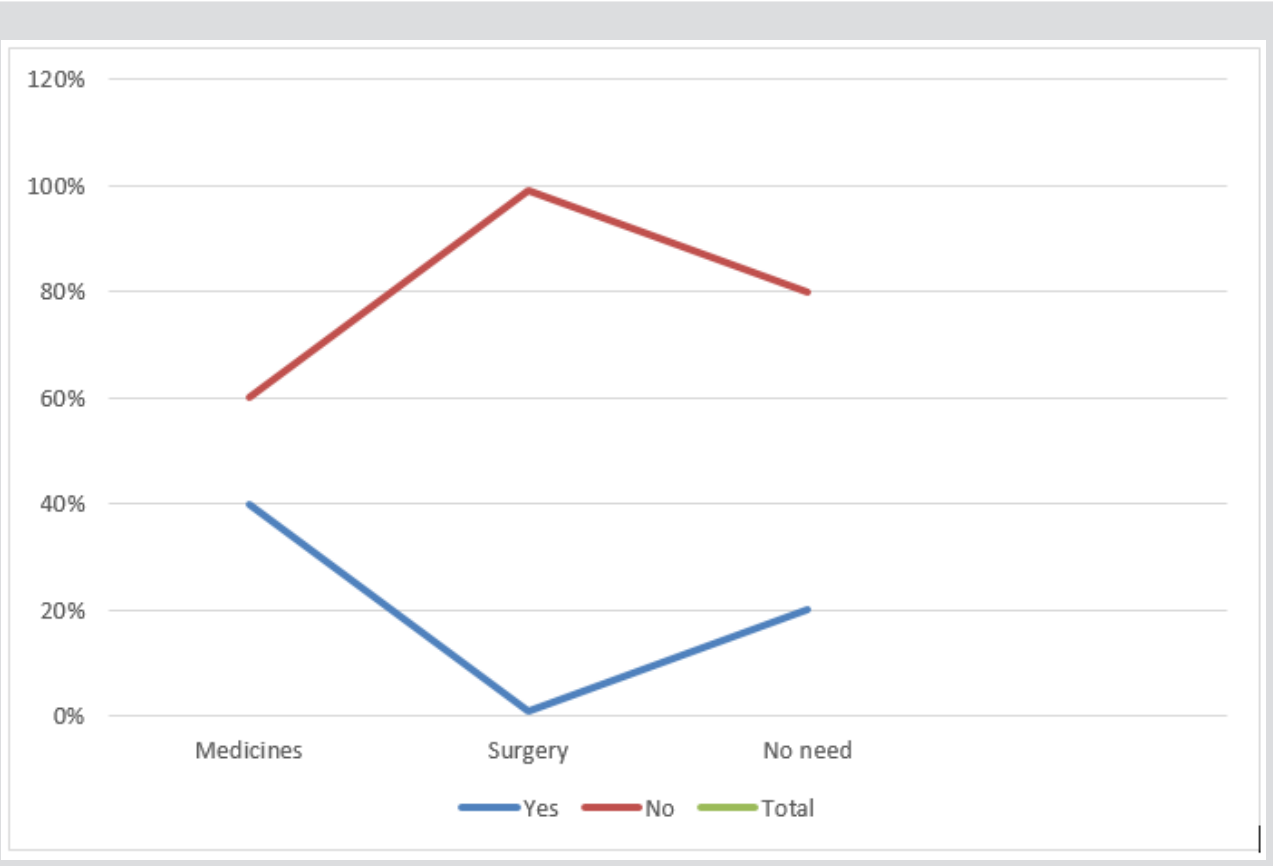

Figure 4: Treatment of Tetanus.

Questionnaire based studies have given an important advancement in the recent researches [3-10]. There are some other researches about Tetanus which shows the comparison between the Tetanus toxin in motor, sensory or adrenergic neurons and retrograde axonal transport of nerve growth factor. Some other studies show that iodegradable microspheres can also be used as controlled-release Tetanus toxoid delivery systems.

\section{Conclusion}

It was concluded form the present study that Tetanus is a bacterial disease. It is not transmitted from parents to children, and there is no need for surgery, although medicines and vaccines can be given.

\section{References}

1. Alonso MJ, Gupta RK, Min C, Siber GR, Langer R (1999) Biodegradable microspheres as controlled-release tetanus toxoid delivery systems. Vaccine 12(4): 299-306.

2. Stoeckel K, Schwab M, Thoenen H (1975) Comparison between the retrograde axonal transport of nerve growth factor and tetanus toxin in motor, sensory and adrenergic neurons. Brain research 99(1): 1-16.

3. Qadir MI, Javid A (2018) Awareness about Crohn's Disease in biotechnology students. Glo Adv Res J Med Medical Sci 7(3): 062-064. 
4. Qadir MI, Saleem A (2018) Awareness about ischemic heart disease in university biotechnology students. Glo Adv Res J Med Medical Sci 7(3): 059-061.

5. Qadir MI, Ishfaq S (2018) Awareness about hypertension in biology students. Int J Mod Pharma Res 7(2): 08-10.

6. Qadir MI, Mehwish (2018) Awareness about psoriasis disease. Int J Mod Pharma Res 7(2): 17-18.

7. Qadir MI, Shahzad R (2018) Awareness about obesity in postgraduate students of biotechnology. Int J Mod Pharma Res 7(2): 14-16.

ISSN: 2574-1241

DOI: 10.26717.BJSTR.2019.14.002581

Tooba Komal. Biomed J Sci \& Tech Res

(c) (i) This work is licensed under Creative

Submission Link: https://biomedres.us/submit-manuscript.php
8. Qadir MI, Rizvi M (2018) Awareness about thalassemia in post graduate students. MOJ Lymphology \& Phlebology 2(1): 14-16.

9. Qadir MI, Ghalia BA (2018) Awareness survey about colorectal cancer in students of M. Phil Biotechnology at Bahauddin Zakariya University, Multan, Pakistan. Nov Appro in Can Study 1(3): NACS.000514.2018.

10. Qadir MI, Saba G (2018) Awareness about intestinal cancer in university student. Nov Appro in Can Study, 1(3): NACS.000515.2018.

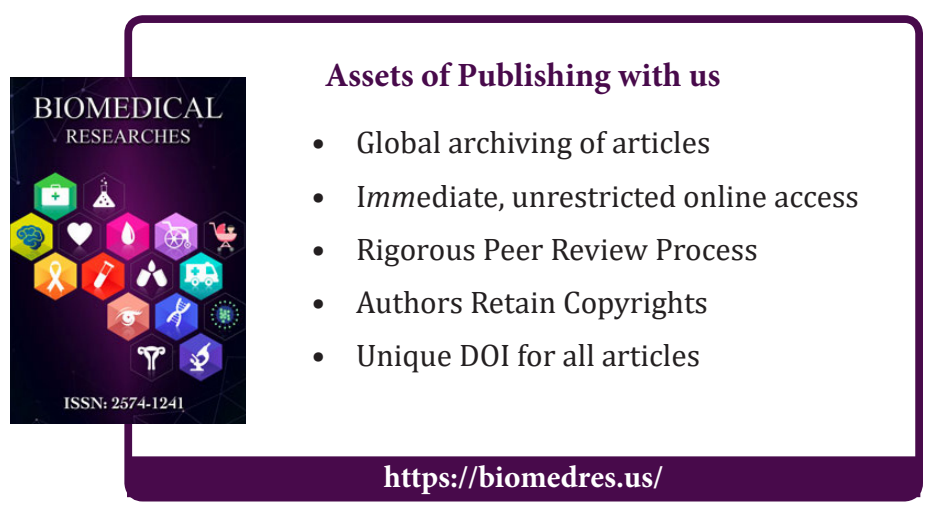

